\title{
SEXUAL VIOLENCE ON UNIVERSITY CAMPUSES: DIFFERENCES AND SIMILARITIES IN THE EXPERIENCES OF STUDENTS, PROFESSORS AND EMPLOYEES
}

\author{
MANON BERGERON \\ UNIVERSTTÉ DU QUÉEEC \\ À MONTRÉAL
}

\author{
MARIE-FRANCE GOYER \\ UNIVERSTTÉ DU QUÉBEC \\ À MONTRÉAL
}

\author{
MARTINE HÉBERT \\ UNIVERSITÉ DU QUÉBEC \\ À MONTRÉAL
}

\author{
SANDRINE RICCI \\ UNIVERSTTÉ DU QUÉBEC \\ À MONTRÉAL
}

\begin{abstract}
This article presents a portrait of sexual violence on university campuses (SVUC) at six universities in Québec (Canada) and explores differences and similarities in the experiences of students, professors and employees. Data are drawn from the Enquête Sexualité, Sécurité et Interactions en Milieu Universitaire (ESSIMU). They reveal disturbing rates of SVUC among students (36.2\%), professors (38.8\%) and employees (38.7\%). The results show that the hierarchical status of perpetrators was higher than that of victims for a significant proportion of professors (33\%) and employees (50.7\%). When asked about the type of assistance they would want in the event of SVUC, the majority of students, professors and employees affirmed they would want support during the reporting/complaint process, information about available recourse within the university to report the incident, and psychological support provided by a resource outside the university.

Keywords: sexual harassment, sexual violence, university, campuses, prevention

\section{Résumé}

Cet article présente un portrait de la violence sexuelle en milieu universitaire (VSMU) sur six campus québécois (Canada) et explore les différences et les similitudes dans l'expérience des étudiant.es, des enseignant.es et des employé.es. Les données proviennent de l'Enquête sur la sexualité, la sécurité et les interactions en milieu universitaire (ESSIMU). Les résultats révèlent des taux inquiétants de VSMU chez les étudiant.es (36,2 \%), les enseignant.es (38,8 \%) et les employé.es (38,7 \%). Les données indiquent que le statut hiérarchique des personnes commettant les gestes de VSMU est supérieur à celui des victimes pour une proportion significative de professeur.es (33\%) et d'employé.es (50,7 \%). Sur la question du type d'aide souhaité en cas de VSMU, la majorité des étudiant.es, enseignant.es et employé.es a affirmé souhaiter un accompagnement dans les démarches de dénonciation ou de plainte, des informations sur les recours possibles pour dénoncer les gestes à l'intérieur de l'université ainsi qu'un soutien psychologique à l'extérieur de l'université.

Mots-clés : harcèlement sexuel, violence sexuelle, université, campus, prévention
\end{abstract}

\section{Introduction}

In Canada and elsewhere, many incidents of sexual violence on university campuses (SVUC) and legal actions taken against universities by survivors have attracted media attention in recent years (Quinlan, E., Quinlan, A., Fogel \& Taylor, 2017). Examples of such incidents include the Saint Mary's University students who chanted slogans celebrating rape culture during initiation week (Tutton, 2013), the sexist, misogynist, and violent messages posted on Facebook by dentistry students at Dalhousie University (Taber, 2014), the sexual assault involving members of the University of Ottawa hockey team (Bradshaw, 2014), the female Université du Québec à Montréal student who was sexually harassed by a professor who, despite the university's formal recognition of the incident, received no sanctions (Elkouri, 2015), and, in the fall of 2016, the series of sexual assaults in a Université Laval student residence (Cloutier, 2016).

Despite growing political and public concern over the last few years, sexual violence in universities is not a new phenomenon. In the United States, feminist students' organizing efforts contributed in part to the adoption in 1972 of Title IX of the Education Amendments, legislation that forced institutions to deal seriously with female 
students' reports of sexual violence (Haaken, 2017). In Canada, pioneering research teams inspired by the rape crisis centre movement revealed high levels of violence against female students (DeKeseredy \& Kelly, 1993). In Québec, the student movement and feminist activists have denounced this problem for over 25 years (Colpron \& Hétu, 1993). Despite this activism for decades and increased attention in recent years, SVUC continues to be a serious and significant problem on Canadian university campuses.

In the present study, the definition of sexual violence covers a broad spectrum of experiences, such as sexual assault, exhibitionism, voyeurism, sexual harassment, cyber harassment, unwanted touching, rape threats, sexual blackmail, and other forms of non-consensual sexual behaviors. This inclusive definition aligns with the approach supported by the Centers for Disease Control and Prevention in the US in its recommendations on monitoring sexual violence (Basile, Smith, Breiding, Black \& Mahendra, 2014). This continuum approach is also consistent with the definition of sexual violence adopted by the World Health Organization in its publication World Report on Violence and Health:

Any sexual act, attempt to obtain a sexual act, unwanted sexual comments or advances, or acts to traffic, or otherwise directed, against a person's sexuality using coercion, by any person regardless of their relationship to the victim, in any setting, including but not limited to home and work. (Krug, Mercy, Dahlberg \& Zwi, 2002, p. 149)

According to the empirical data, the rates of sexual violence vary depending on the reporting period used (e.g. the last 12 months or since arriving on campus) and the definition of "sexual violence" (e.g. including non-contact forms of victimization such as sexual harassment or only contact-forms of sexual assault). For example, a study conducted at the University of Ottawa (2015) reports that $16 \%$ of women and $8 \%$ of men respondents reported having experienced at least one incident of sexual assault (with contact) since arriving on campus. With regard to face-to-face harassment, $78 \%$ of female students and $49 \%$ of male students had been harassed at least once since arriving at the university. Another example is the research of Fedina, Holmes and Backes (2016), who produced a review of 34 studies published between 2000 and 2015 on the prevalence of sexual violence experi- enced by US college and university students, excluding sexual harassment. Fedina et. Al (2016) found that, in the 10 studies using a broad definition of sexual assault (unwanted sexual touching, rape and attempted rape), prevalence varied between $6 \%$ and $44.2 \%$ among female students, and between $1.4 \%$ and $3.2 \%$ among male students. With regard to sexual assault with penetration, rates fluctuate from $0.5 \%$ to $8.4 \%$ among women, and from $0.6 \%$ to $0.7 \%$ among men.

A study of Canadian students' negative experiences during their studies (e.g. interpersonal conflicts) shows that sexual assault caused the most deleterious consequences on students' quality of life and academic performance (Tremblay et al., 2008). In fact, incidents of SVUC are linked to numerous health consequences such as intrusive thoughts and nightmares, a heightened state of vigilance, the avoidance of situations conducive to harassment and specific locations, and depressive or panic symptoms (Bastiani, Romito \& Saurel-Cubizolles, 2018; Hill \& Silva, 2005; University of Ottawa, 2015). Other repercussions specific to academia were also documented: diminished academic performance, higher absentee rate, problems concentrating in class, difficulty completing assignments, even deciding to leave the university (Banyard, Ward, Cohn, Plante, Moorhead, \& Walsh , 2007; Hill \& Silva, 2005; Krebs et al., 2016). According to the study conducted by the University of Ottawa (2015), student victims of sexual violence involving physical contact are not the only ones who reported experiencing negative health consequences. Results showed that "the impact of harassment on students is broad and varied and more commonly reported by women than by men" (p. 15). Among students victims to face-to-face harassment, 34\% reported having avoided situations related to the harassment, $32 \%$ were constantly on guard or easily startled and $20 \%$ suffered from nightmares or recurring thoughts (University of Ottawa, 2015).

While the presence of SVUC and some of its consequences are known and recognized, Canadian postsecondary institutions pay varying degrees of attention to the issue of sexual assault on campuses (Quinlan, Clarke \& Miller, 2016). According to the Canadian Federation of University Women (2016), many campuses are ill equipped to handle reported incidents of SVUC. They apply disciplinary measures that lack clarity, provide inadequate institutional support, and available assistance is either inaccessible or non-existent (Canadian Federation of University Women, 2016). Additionally, uni- 
versity violence policies are not standardized (Quinlan et al., 2016). The recent legislation adopted in several Canadian provinces, particularly Ontario (Government of Ontario, n.d.), British Columbia (Government of British Columbia, n.d.) and Québec (Government of Québec, n.d.), is undoubtedly a key SVUC prevention tool. To encourage implementation of institutional policies and adequate prevention strategies, fuller understanding of SVUC is needed, including a description of the dynamics specific to academic settings and the interventions best suited to the institutions.

Few studies have focused on SVUC in Canada (Quinlan et al., 2016), but according to the Canadian 2004 General Social Survey on victimization, students have significantly higher rates of sexual assault than young adults who report working as their main activity (Brennan \& Taylor-Butts, 2008). Studies have documented the phenomenon of SVUC in the United States (Fedina et al., 2016; Fisher, Cullen \& Turner, 2000; Krebs, Lindquist, Warner, Fisher \& Martin, 2007), but most focus simply on sexual violence experienced by students during the period of university attendance, regardless of whether it was committed by individuals affiliated with the university. These data are thus not specifically linked to SVUC because the incidents may have occurred in a private context with a perpetrator unrelated to the institution (e.g., family member, intimate partner or coworker outside university). Professors and other employee groups may also be victims of sexual harassment (Baker, 2010; Iconis, 2006). Yet, most previous research has been based on student samples only, thus omitting all employee groups who are also potential targets of SVUC in one form or another. The issue of sexual violence affects all members of the university community, whether as individuals directly involved in incidents of SVUC, or as witnesses or confidants. This reality commands that we document the phenomenon by including all groups in the research and action processes, students, professors and employees.

\section{Feminist Framework}

Our analysis framework is based on a broad definition of sexual violence, as explained earlier, and aligns with a paradigm developed by numerous feminist researchers, practitioners and activists, going back to the pioneering work of Kelly (1987) and Hanmer (1977), in which sexual violence is conceived beyond legal categories, as gen- dered, systemic, and along a continuum. This approach highlights the analytical and empirical connections between various forms of gender-based violence, which have a cumulative effect upon the individual as well as a negative impact on all women as a social group. In addition, because sexual comments, harassment, and blackmail or pressure to have sex tend to occur more often than physical attacks, situating sexual violence along a continuum helps to uncover how unequal power relations operate.

\section{Objectives and Contributions}

This article will add to the current body of research on SVUC by providing a portrait of SVUC in the Québec context and exploring differences in the experience of students, professors and employees with data drawn from the Enquête Sexualité, Sécurité et Interactions en Milieu Universitaire (ESSIMU): Ce qu'en disent étudiant.es, enseignant.es et employé.es [Study on Sexuality, Security and Interactions on a University Campus: What Students, Professors and Employees are Saying] (Bergeron et al., 2016). In contrast to previous studies based on samples composed exclusively of students, this article also documents the still relatively unknown experiences of other groups in the university community. We examined similarities and differences across status with regard to different forms of SVUC, characteristics of the perpetrators, consequences, reasons for not reporting to the university, and the assistance expected from the university.

In addition to distinguishing between three groups, this study is unique in two other areas. First, it specifically documents the incidence of sexual violence on university campuses. The expression "university campuses" refers to the fact that the individuals involved are affiliated to the same university, regardless of the location of the event (e.g. inside or outside campuses, in physical or virtual environment). Second, since the reporting period influences percentages of victimization, this study documents two periods: within the past 12 months and since the arrival at the university. The Enquête Sexualité, Sécurité et Interactions en Milieu Universitaire (ESSIMU) survey is distinguished by its methodological choices that were designed to compensate for the limitations of previous studies. 


\section{Methodology}

The data for this article comes from the Enquête Sexualité, Sécurité et Interactions en Milieu Universitaire (ESSIMU) survey conducted in Québec, a broad survey of students, professors (also including lecturers and thesis directors), and other employees at six francophone universities concerning sexual violence on university campuses (Bergeron et al., 2016). The sole criterion for completing the online questionnaire was that participants be either employed or studying at one of the six universities at the time of data collection (January to May 2016). Following approval from the research ethics committees, the sample was mainly recruited through email invitations sent to the entire university community at each site, using the institutional email lists. In one instance, access to an email list was declined: other recruitment strategies were used, such as posting online videos that described the study and posting invitations in the busy areas of the University (e.g. cafeterias). The overall convenience sample consisted of 9,284 participants; we used a subsample of 9,145 students, professors and employees for the present analysis ${ }^{1}$.

\section{Participants}

The breakdown of the sample $(n=9,145)$ was as follows: $71.7 \%$ students $(46.6 \%$ undergraduate students and $25.0 \%$ graduate students) 2 ; $13.3 \%$ professors (including lecturers and thesis directors); and $15.0 \%$ employees. In each participant category women formed the majority (73.8\% among students; $54.3 \%$ among professors; and $75.3 \%$ among employees). Table 1 presents the sociodemographic characteristics of the sample by university status.

Table 1. Frequency of Socio-Demographic Characteristics for the Sample, by Status $(n=9145)$

\begin{tabular}{|c|c|c|c|}
\hline & $\begin{array}{c}\text { Student } \\
71.7 \\
(6554)\end{array}$ & $\begin{array}{c}\text { Professor } \\
13.3 \\
(1220)\end{array}$ & $\begin{array}{c}\text { Employee } \\
15.0 \\
(1371)\end{array}$ \\
\hline & $\%$ & $\%$ & $\%$ \\
\hline \multicolumn{4}{|c|}{ Period of university attendance/employment } \\
\hline sone year & 25.3 & 3.6 & 4.2 \\
\hline$>1$ year to 3 years & 41.3 & 8.4 & 10.3 \\
\hline$>3$ years to 5 years & 18.2 & 10.1 & 12.0 \\
\hline$>5$ years & 15.2 & 78.0 & 73.6 \\
\hline \multicolumn{4}{|l|}{ Age } \\
\hline 18 - 25 years old & 64.7 & 2.7 & 4.7 \\
\hline 26 - 35 years old & 26.2 & 13.8 & 26.2 \\
\hline 36 - 45 years old & 6.3 & 30.1 & 29.2 \\
\hline 46 - 55 years old & 2.1 & 26.4 & 26.4 \\
\hline$\geq 56$ years old & 0.7 & 27.0 & 13.6 \\
\hline \multicolumn{4}{|l|}{ Gender } \\
\hline Women & 73.8 & 54.3 & 75.3 \\
\hline Men & 24.5 & 44.9 & 24.3 \\
\hline Gender minorities & 1.8 & - & - \\
\hline \multicolumn{4}{|l|}{ Sexual orientation } \\
\hline Heterosexual & 84.2 & 91.2 & 93.5 \\
\hline Sexual minorities & 14.2 & 8.8 & 6.1 \\
\hline
\end{tabular}




\begin{tabular}{lccc}
\hline & Student & Professor & Employee \\
& 71.7 & 13.3 & 15.0 \\
& $(6554)$ & $(1220)$ & $(1371)$ \\
\hline & $\%$ & $\%$ & $\%$ \\
Uncertain / questioning & & & - \\
Self-declared as a member of a visible minority & 1.6 & - & 2.6 \\
Self-declared as a member of an indigenous community & 7.6 & 2.9 & 2.5 \\
\hline
\end{tabular}

Note. For cells with 10 or fewer individuals, the data is replaced by a hyphen.

\section{Measures}

\section{Sociodemographic characteristics}

Documented characteristics included gender, age, sexual orientation, membership in a visible minority group, member of an Indigenous community, current period of university attendance or employment, and current principal status at the university.

\section{Gender}

Gender was determined by two questions. Respondents first answered whether they identified as a man, woman, non-binary, or other; they then indicated whether their current gender identity was different from that assigned to them at birth. Answers were recoded into groups: women, men, and gender minorities. In this article, the term "gender minorities" refers to individuals who did not answer that they were a man or woman whose gender identity corresponds to that assigned to them at birth; trans and non-binary individuals were included under this term.

\section{Sexual orientation}

Respondents indicated their sexual orientation and these answers were recoded into three groups: heterosexual, sexual minorities, or uncertain/questioning. The term "sexual minorities" refers to individuals who answered the question on sexual orientation by stating they were homosexual, gay, lesbian, bisexual, two-spirited, genderqueer, pansexual, or asexual, or chose "other."

\section{University status}

Participants were asked to select their principal status at the university from a list of possible choices. Answers were recoded into four groups: student, professor, employee, and manager.

\section{Sexual violence}

Sexual violence was measured using a French adaptation of the Sexual Experiences Questionnaire (SEQDoD) which has previously been used by Fitzgerald, Magley, Drasgow and Waldo (1999). It includes a total of 21 items and three subscales: 1 ) sexual harassment (verbal and non-verbal insults and hostile or degrading behaviors); 2) unwanted sexual behaviors (verbal and non-verbal behaviors of a sexual, offensive, unwanted, or non-reciprocal nature, including attempted rape and sexual assault); 3) sexual coercion (blackmail involving promises of future benefits related to jobs or studies or reprisal if sexual favours were not given). Internal consistency reliability for these three dimensions (respectively $.84, .83$, and .86) and for the overall scale (.89) is adequate. Three of the questions on the unwanted sexual behaviors dimension addressed unwanted sexual behaviors with contact. To increase comparability to previous research on sexual assault, a separate scale looking exclusively at unwanted sexual behaviors with contact was included in the analyses (USB-with contact). To obtain more details on the development of this scale and its implications, we recommend consulting the articles of Fitzgerald and colleagues (1988; 1995; 1999). For each question, participants were asked how many times an individual affiliated with the university committed these act against them. They were given a set of possible responses (never, 1 time, 2-3 times, 4-5 times, +5 times). This section of the questionnaire thus provided two reporting periods for consideration (within the past 12 months and since the arrival at the university). Answers were recoded into dichotomous variables for each item and each dimension of the instrument. 


\section{Characteristics of perpetrators involved in SVUC incidents}

Respondents who reported at least one incident of SVUC answered a series of questions concerning the characteristics of the incidents. A set of questions documented the characteristics of the individuals who committed the acts of SVUC (referred to as perpetrators in this article): gender, status at the time of the incident (e.g., student, professor, manager, etc.) and their hierarchical relationship to the victim (inferior, equal, or superior). Multiple choice answers gave respondents a chance to select one or more answers to the questions. The answers were recoded into dichotomous variables (yes/no).

\section{Consequences of SVUC events}

Participants who experienced at least one incident of SVUC were questioned about the consequences of SVUC in terms of impact on academic, professional, or athletic performance (two items), personal and social life (two items), physical health (three items) and mental health (four items). Items linked to the first three dimensions were inspired by instruments developed by Banyard et al. (2007) and the University of Ottawa (2015), except the item "experienced different forms of physical discomfort (e.g., headaches, nausea, pain)", which was formulated by co-researchers at the Université de Montréal. The four items evaluating mental health $(\alpha$ $=0.75$ ) query the condition of post-traumatic stress by means of the Primary Care PTSD instrument (Prins et al., 2004). For each of the 11 items, the respondent indicated whether they had experienced this repercussion following an incident of SVUC (yes/no). The internal consistency coefficient for the overall instrument was 0.87 .

\section{Reporting/disclosure}

Individuals who reported at least one incident of SVUC answered the question "Did you report the incidents to university authorities/resources?" Individuals who either did not report an incident or only reported certain incidents were then asked for the reasons they did not report the incidents, with a choice of 16 statements inspired by the studies of Cantin and Proulx (1995) and Krebs et al. (2007).

\section{Type of assistance desired}

All respondents, whether or not they had experienced SVUC, were asked to answer the question "If you were to experience sexual harassment or violence committed by someone connected with the university (or if you have already experienced it), what type of assistance would you want?" Participants chose one or more answers from a list of nine possibilities (including "other, specify").

\section{Witness/confidant}

Participants answered two questions about being a witness and/or confidant with regard to an incident of SVUC. For each situation, the individual could select answers ranging from "never" to "more than five times." The answers were recoded into dichotomous variables (yes/no).

\section{Analysis}

The Chi-square test with Bonferroni-corrected post hoc comparisons was used to compare students, professors and employees in terms of each variable of interest. Effect sizes are presented in the tables and can be interpreted using Cohen's (1988) suggested guidelines for small, medium and large effects ${ }^{3}$. Analyses were conducted using SPSS version 23.0.

\section{Results}

While the frequency of SVUC reported by participants since arriving at the university did not vary in terms of university statuses (except for subscale USB-with contact), these data reveal significant differences in the frequency of SVUC experienced during the past 12 months (Table 2). First, over one third of the sample indicated having experienced at least one incident of SVUC committed by someone connected with the university since they began studying or working at the university (students, $36.2 \%$; professors, 38.8\%; and employees, 38.7\%). When we consider only the 12 months preceding the study, more students reported experiencing at least one incident of SVUC in the past-year period (27.6\%) than professors $(16.2 \%)$ and employees $(19.0 \%)\left(\chi^{2}(2)=100.6, p<.001\right)$. As shown in Table 2, this significant difference between students and the other status groups was found for all forms of SVUC. For the period of the last 12 months, more students $(24.9 \%)$ reported having experienced at least one incident of $\mathrm{SH}$ than professors (14.7\%) and employees $(17.3 \%)\left(\chi^{2}(2)=85.9, p<.001\right)$; a larger proportion of students (12.3\%) reported having experienced at least one incident of USB than professors (5.2\%) and employees $(5.8 \%)\left(\chi^{2}(2)=90.2, p<.001\right)$; also, students 
were more likely $(6 \%)$ to report at least one incident of USB-with contact than professors (1.2\%) and employees $(1.8 \%)\left(\chi^{2}(2)=82.5, p<.001\right)$; and students $(1.6 \%)$ were significantly more numerous in reporting having experienced at least one incident of SC than professors $(0.7 \%)$ and employees $(0.4 \%)\left(\chi^{2}(2)=15.6, p<.001\right)$. report at least one incident of SVUC than men and women $\left(\chi^{2}(2)=173.2, \quad p<.001\right)$. Table 3 presents the data broken down by university status. Because of the scarcity of individuals identifying as members of gender minorities among the students and professors (see Table 1), we cannot present reliable estimates for each form of SVUC.

Table 2. Proportion of Participants Reporting SVUC Events, by Status

\begin{tabular}{lcccccc}
\hline & $\begin{array}{c}\text { Student } \\
\%\end{array}$ & $\begin{array}{c}\text { Professor } \\
\%\end{array}$ & $\begin{array}{c}\text { Employee } \\
\%\end{array}$ & $\chi^{2}$ & $p$ & $\begin{array}{c}\text { Effect sizes } \\
\phi^{\prime}\end{array}$ \\
\hline SVUC since arriving to university & & & & & & \\
SH & 32.9 & 34.9 & 34.8 & 3.3 & .192 & .019 \\
USB & 18.2 & 18.2 & 19.1 & .62 & .732 & .008 \\
USB-with contact & $9.1^{\mathrm{a}}$ & $6.8^{\mathrm{b}}$ & $6.6 \mathrm{~b}$ & 14.7 & .001 & .04 \\
SC & 3.1 & 4.0 & 2.7 & 4.1 & .126 & .021 \\
At least 1 event of SVUC & 36.2 & 38.8 & 38.7 & 4.9 & .085 & .023 \\
\hline SVUC in the 12 last months & & & & & & \\
SH & $24.9^{\mathrm{a}}$ & $14.7^{\mathrm{b}}$ & $17.3^{\mathrm{b}}$ & 85.9 & $<.001$ & .097 \\
USB & $12.3^{\mathrm{a}}$ & $5.2^{\mathrm{b}}$ & $5.8^{\mathrm{b}}$ & 90.2 & $<.001$ & .099 \\
USB-with contact & $6.0^{\mathrm{a}}$ & $1.2^{\mathrm{b}}$ & $1.8^{\mathrm{b}}$ & 82.5 & $<.001$ & .095 \\
SC & $1.6^{\mathrm{a}}$ & - & - & 15.6 & $<.001$ & .041 \\
At least 1 event of SVUC & $27.6^{\mathrm{a}}$ & $16.2^{\mathrm{b}}$ & $19.0^{\mathrm{b}}$ & 100.6 & $<.001$ & .105 \\
\hline Note. SVUC = Sexual Violence on University Campuses; SH = Sexual Harassment; USB = Unwanted Sexual Behaviors; SC = \\
$\quad$ Sexual Coercion. Proportions that do not share the same letters statistically differ at $p<.05$ in Bonferroni-corrected post hoc \\
$\quad$ comparisons. For cells with 10 or fewer individuals, the data is replaced by a hyphen. & &
\end{tabular}

Table 3. Proportion of Participants Reporting at least one event of SVUC since arriving to university, by gender

\begin{tabular}{lcccccc}
\hline & Women & Men & $\begin{array}{c}\text { Gender } \\
\text { minorities }\end{array}$ & $\chi^{2}$ & $p$ & Effect sizes $\phi^{\prime}$ \\
\hline Student & $39.2^{\mathrm{a}}$ & $26.0^{\mathrm{b}}$ & $54.3^{\mathrm{c}}$ & 107.2 & $<.001$ & .128 \\
Professor & $47.1^{\mathrm{a}}$ & $27.8^{\mathrm{b}}$ & - & 54.5 & $<.001$ & .211 \\
Employee & $42.6^{\mathrm{a}}$ & $26.4^{\mathrm{b}}$ & - & 27.8 & $<.001$ & .142 \\
\hline
\end{tabular}

Note. Proportions that do not share the same letters statistically differ at $\mathrm{p}<.05$ in Bonferroni-corrected post hoc comparisons.

For cells with 10 or fewer individuals, the data is replaced by a hyphen.

The data reveal a significant association between gender and frequency of SVUC since arriving at university. Overall, more women (40.5\%) than men (26.5\%) reported having experienced at least one incident of sexual violence committed by someone connected to the university. Also, gender minority participants were more likely $(55.7 \%)$ to

\section{Characteristics of Perpetrators of SVUC}

The characteristics of individuals who perpetrated SVUC reported by survey participants vary depending on university status (Table 4). First, the data show that in the great majority of incidents (between $78.4 \%$ and $92.1 \%$ 
depending on the status), the perpetrator was identified as male in at least one situation. However, the perpetrator was identified as female in at least one incident of SVUC significantly more often among professor/victims (35.2\%) than student/victims (28.3\%) or employee/victims (22.5\%). Note that the total exceeds $100 \%$ because respondents could check more than one answer (if more than one SVUC incident occurred).
The data also reveal that most respondents who indicated they were victims of SVUC mentioned that they had a non-hierarchical academic or professional relationship with the perpetrator (equivalent status ranging from $55.2 \%$ to $87.4 \%$ depending on university status). The proportion of incidents involving an individual with superior status is nonetheless quite high in all three groups: the hierarchical status of the person who committed the acts

Table 4. Gender of the Perpetrator and Hierarchical Relationship with the Victim, by Status

\begin{tabular}{|c|c|c|c|c|c|c|}
\hline & $\begin{array}{c}\text { Student } \\
\%\end{array}$ & $\begin{array}{c}\text { Professor } \\
\% \\
\end{array}$ & $\begin{array}{c}\text { Employee } \\
\% \\
\end{array}$ & $\chi^{2}$ & $p$ & $\begin{array}{c}\text { Effect } \\
\text { sizes } \phi^{\prime}\end{array}$ \\
\hline \multicolumn{7}{|c|}{ Since arriving to university } \\
\hline \multicolumn{7}{|l|}{ svUC } \\
\hline \multicolumn{7}{|c|}{ Gender of perpetrator } \\
\hline Woman & $28.3^{\mathrm{a}}$ & $35.2^{b}$ & $22.5^{\mathrm{c}}$ & 19.2 & $<.001$ & .076 \\
\hline Men & $91.0^{\mathrm{a}}$ & $78.4^{b}$ & $92.1^{\mathrm{a}}$ & 68.6 & $<.001$ & .144 \\
\hline \multicolumn{7}{|c|}{ Hierarchical status... } \\
\hline Lower & $5.0^{\mathrm{a}}$ & $46.2^{b}$ & $25.9^{c}$ & 606.0 & $<.001$ & .430 \\
\hline Equivalent & $87.4^{\mathrm{a}}$ & $58.2^{b}$ & $55.2^{b}$ & 381.5 & $<.001$ & .341 \\
\hline Higher & $25.0^{\mathrm{a}}$ & $33.0^{\mathrm{b}}$ & $50.7^{c}$ & 132.0 & $<.001$ & .201 \\
\hline \multicolumn{7}{|l|}{ SH } \\
\hline \multicolumn{7}{|c|}{ Gender of perpetrator } \\
\hline Woman & $27.4^{\mathrm{a}}$ & $32.1^{\mathrm{a}}$ & $20.1^{b}$ & 16.8 & $<.001$ & .075 \\
\hline Man & $90.9^{\mathrm{a}}$ & $80.1^{b}$ & $93.5^{\mathrm{a}}$ & 51.4 & $<.001$ & .131 \\
\hline \multicolumn{7}{|c|}{ Hierarchical status... } \\
\hline Lower & $4.4^{\mathrm{a}}$ & $41.7^{b}$ & $22.7^{\mathrm{c}}$ & 490.2 & $<.001$ & .407 \\
\hline Equivalent & $86.4^{\mathrm{a}}$ & $58.5^{b}$ & $54.8^{\mathrm{b}}$ & 316.1 & $<.001$ & .327 \\
\hline Higher & $25.1^{\mathrm{a}}$ & $32.8^{b}$ & $50.2^{c}$ & 114.1 & $<.001$ & .196 \\
\hline \multicolumn{7}{|l|}{ USB } \\
\hline \multicolumn{7}{|c|}{ Gender of perpetrator } \\
\hline Woman & $15.8^{\mathrm{a}}$ & $29.6^{b}$ & $17.4^{\mathrm{a}}$ & 23.4 & $<.001$ & .119 \\
\hline Men & $89.0^{\mathrm{a}}$ & $76.1^{\mathrm{b}}$ & $86.4^{\mathrm{a}}$ & 26.5 & $<.001$ & .127 \\
\hline \multicolumn{7}{|c|}{ Hierarchical status... } \\
\hline Lower & $4.4^{\mathrm{a}}$ & $43.5^{b}$ & $24.7^{c}$ & 291.1 & $<.001$ & .421 \\
\hline Equivalent & $84.7^{a}$ & $45.3^{b}$ & $46.3^{b}$ & 260.8 & $<.001$ & .399 \\
\hline Higher & $18.2^{\mathrm{a}}$ & $26.6^{\mathrm{b}}$ & $40.8^{c}$ & 62.9 & $<.001$ & .196 \\
\hline
\end{tabular}

SC

Gender of perpetrator 


\begin{tabular}{lcccccc}
\hline & $\begin{array}{c}\text { Student } \\
\%\end{array}$ & $\begin{array}{c}\text { Professor } \\
\%\end{array}$ & $\begin{array}{c}\text { Employee } \\
\%\end{array}$ & $\chi^{2}$ & $p$ & $\begin{array}{c}\text { Effect } \\
\text { sizes } \phi^{\prime}\end{array}$ \\
\hline Woman & $18.9^{\mathrm{a}}$ & $34.0^{\mathrm{a}}$ & $34.3^{\mathrm{a}}$ & 7.5 & .023 & .165 \\
Man & $87.2^{\mathrm{a}}$ & $76.6^{\mathrm{a}}$ & $77.1^{\mathrm{a}}$ & 4.7 & .095 & .130 \\
Hierarchical status... & & & & & & \\
$\quad$ Lower & - & $25.5^{\mathrm{b}}$ & - & 19.4 & $<.001$ & .265 \\
Equivalent & $73.7^{\mathrm{a}}$ & $23.4^{\mathrm{b}}$ & $31.4^{\mathrm{b}}$ & 53.2 & $<.001$ & .439 \\
Higher & $31.4^{\mathrm{a}}$ & $66.0^{\mathrm{b}}$ & $62.9^{\mathrm{b}}$ & 26.3 & $<.001$ & .309 \\
\hline
\end{tabular}

Note. SVUC = Sexual Violence on University Campuses; $\mathrm{SH}=$ Sexual Harassment; USB = Unwanted Sexual Behaviors; $\mathrm{SC}=$ Sexual Coercion. Proportions that do not share the same letters statistically differ at $p<.05$ in Bonferroni-corrected post hoc comparisons. For cells with 10 or fewer individuals, the data is replaced by a hyphen.

was higher than that of the victim significantly more often among employees (50.7\%) than among the other two groups, and significantly more often among professors (33.0\%) than students (25.0\%). Table 4 presents findings specific to each form of SVUC.

\section{Consequences of SVUC}

Individuals who reported at least one incident of SVUC were asked about the repercussions they experienced. In all, $47.6 \%$ of the sample reported having experienced at least one consequence that affected their academic, professional, or athletic success (e.g., intending or having changed their academic, athletic, or professional career), personal/social life (e.g., problems in their emotional, sexual/intimate relationships), physical (e.g., increased consumption of alcohol or drugs) or mental health (e.g., being constantly on guard, in a state of alert, or jumpy). The data reveal that significantly more students $(50.0 \%)$ reported having experienced at least one consequence than professors (40.9\%) and employees (42.5\%) $\left(\chi^{2}(2)=\right.$
19.7, $p<.001$ ). Some of the reported symptoms are linked to the dimensions related to post-traumatic stress such as avoidance, hypervigilance, and re-experiencing (e.g., impression of reliving the incident). A similar proportion of students (9.5\%), professors (7.2\%) and employees $(10.5 \%)$ attained the clinical threshold for post-traumatic stress $\left(\chi^{2}(2)=3.3, p=.192\right)$.

\section{Reporting Incidents}

A total of $95.6 \%$ of respondents who experienced one or more incidents of SVUC did not report any of the incidents $(90.7 \%)$, or only some of the incidents $(4.9 \%)$ to university authorities or resources. Significantly fewer students $(3.3 \%)$ reported all the incidents they experienced compared to professors (6.9\%) and employees $(7.2 \%)\left(\chi^{2}(2)=22.6, p<.001\right)$. Victims who did not report one or more incidents of SVUC to university resources or authorities were asked an additional question to learn the reasons for not reporting (Table 5).

Table 5. Reasons for not reporting event of SVUC, by Status

\begin{tabular}{|c|c|c|c|c|c|c|}
\hline & $\begin{array}{l}\text { Student } \\
\quad \%\end{array}$ & $\begin{array}{l}\text { Professor } \\
\quad \%\end{array}$ & $\begin{array}{l}\text { Employee } \\
\%\end{array}$ & $\chi^{2}$ & $p$ & $\begin{array}{c}\text { Effect } \\
\text { sizes } \\
\phi^{\prime}\end{array}$ \\
\hline I thought the situation was not serious enough to report & $79.8^{\mathrm{a}}$ & $73.6^{\mathrm{a}}$ & $76.5^{\mathrm{a}}$ & 5.6 & .062 & .055 \\
\hline $\begin{array}{l}\text { I just wanted to put the incident behind me and forget } \\
\text { about it }\end{array}$ & $31.4^{\mathrm{a}}$ & $21.2^{\mathrm{b}}$ & $30.2^{\mathrm{ab}}$ & 10.4 & .006 & .076 \\
\hline $\begin{array}{l}\text { I was worried that university authorities would not take the } \\
\text { situation seriously }\end{array}$ & $21.0^{\mathrm{a}}$ & $16.4^{\mathrm{a}}$ & $20.7^{\mathrm{a}}$ & 2.8 & .247 & .039 \\
\hline $\begin{array}{l}\text { I worried that I didn't have enough proof to convince uni- } \\
\text { versity authorities to intervene }\end{array}$ & $21.2^{\mathrm{a}}$ & $14.0^{\mathrm{b}}$ & $17.9^{\mathrm{ab}}$ & 7.5 & .023 & .064 \\
\hline
\end{tabular}




\begin{tabular}{|c|c|c|c|c|c|c|}
\hline & $\begin{array}{l}\text { Student } \\
\%\end{array}$ & $\begin{array}{l}\text { Professor } \\
\quad \%\end{array}$ & $\begin{array}{l}\text { Employee } \\
\%\end{array}$ & $\chi^{2}$ & $p$ & $\begin{array}{c}\text { Effect } \\
\text { sizes } \\
\phi^{\prime}\end{array}$ \\
\hline I didn't know who to contact at the university & $19.3^{\mathrm{a}}$ & $9.2^{b}$ & $10.2^{b}$ & 25.3 & $<.001$ & .118 \\
\hline $\begin{array}{l}\text { I worried about reprisals by the attacker or someone close } \\
\text { to them }\end{array}$ & $15.7^{\mathrm{a}}$ & $16.4^{\mathrm{a}}$ & $18.2^{\mathrm{a}}$ & 1.2 & .558 & .025 \\
\hline $\begin{array}{l}\text { I didn't trust the people or existing university authorities/ } \\
\text { resources }\end{array}$ & $15.2^{\mathrm{a}}$ & $16.4^{\mathrm{a}}$ & $18.9^{\mathrm{a}}$ & 2.5 & .286 & .037 \\
\hline $\begin{array}{l}\text { I was afraid people would think I was partly responsible } \\
\text { for the situation }\end{array}$ & $15.1^{\mathrm{a}}$ & $13.6^{\mathrm{a}}$ & $13.0^{\mathrm{a}}$ & 1.1 & .587 & .024 \\
\hline $\begin{array}{l}\text { I was afraid my complaint would not be handled confiden- } \\
\text { tially }\end{array}$ & $13.9^{\mathrm{a}}$ & $16.4^{\mathrm{a}}$ & $15.4^{\mathrm{a}}$ & 1.4 & .509 & .027 \\
\hline $\begin{array}{l}\text { I thought the reporting process at the university was too } \\
\text { complicated }\end{array}$ & $15.7^{\mathrm{a}}$ & $10.4^{\mathrm{a}}$ & $10.5^{\mathrm{a}}$ & 8.4 & .015 & .068 \\
\hline I didn't know the university could help me in this situation & $15.6^{\mathrm{a}}$ & $8.0^{b}$ & $9.8^{\mathrm{b}}$ & 14.4 & .001 & .089 \\
\hline $\begin{array}{l}\text { I feared negative consequences on my job, academic ses- } \\
\text { sion, getting my degree, athletic career }\end{array}$ & $10.4^{\mathrm{a}}$ & $18.0^{\mathrm{b}}$ & $18.9^{b}$ & 22.1 & $<.001$ & .110 \\
\hline I didn't want anyone to know about this situation & $12.3^{\mathrm{a}}$ & $10.4^{\mathrm{a}}$ & $11.9^{\mathrm{a}}$ & 0.7 & .697 & .020 \\
\hline $\begin{array}{l}\text { I was afraid of negatively affecting the job or studies of the } \\
\text { person to committed these acts }\end{array}$ & $10.4^{\mathrm{a}}$ & $9.6^{\mathrm{a}}$ & $9.1^{\mathrm{a}}$ & 0.5 & .794 & .016 \\
\hline $\begin{array}{l}\text { I needed help or a break, but I didn't want to make a formal } \\
\text { complaint }\end{array}$ & $5.1^{a}$ & $6.4^{a}$ & $3.9^{a}$ & 1.8 & .411 & .031 \\
\hline
\end{tabular}

Note. Proportions that do not share the same letters statistically differ at $p<.05$ in Bonferroni-corrected post hoc comparisons.

In the three groups, over $70 \%$ of the participants said they did not report the incident at the university because they thought the situation was not serious enough to report. While most of the reasons were selected by similar numbers of students, professors and employees, some differences were observed, especially in the student group. Students were significantly more likely (31.4\%) than professors (21.2\%) to not report SVUC incidents because they wanted to put it behind them and forget about it $\left(\chi^{2}(2)=10.4, p=.006\right)$. The same is true regarding the fear of not having enough evidence to convince university authorities to intervene, a reason given significantly more often by students (21.2\%) than professors $(14.0 \%)$ $\left(\chi^{2}(2)=7.5, p=.023\right)$. Students were significantly more susceptible than professors and employees to state they did not know who to contact at the university (students: 19.3\%; professors: 9.2\%; employees: $10.2 \% ; \chi^{2}(2)=$ $25.3, p<.001$ ) or even whether the university could help them in this situation (students, 15.6\%; professors, $8.0 \%$; employees, 9.8\%; $\left.\chi^{2}(2)=14.4, p=.001\right)$. Students were, however, significantly less numerous (10.4\%) than professors (18.0\%) and employees (18.9\%) in mentioning they did not report out of a fear of negatives consequences on their job, academic session, obtaining their degree, or athletic career $\left(\chi^{2}(2)=22.1, p<.001\right)$.

\section{Type of Assistance Desired}

When asked about the type of assistance they wanted following an incident of SVUC, most participants chose support in the report/complaint process (students: $71.1 \%$; professors: $64.6 \%$; employees: $72.0 \% ; \chi^{2}(2)=22.5, p<$ .001 ), information on possible recourse available within the university to report the incident (students, 55.4\%; professors, 53.4\%; employees, $54.0 \% ; \chi^{2}(2)=2.1, p=.357$ ) and psychological support provided by a resource outside the university (students, 55.2\%; professors, 53.0\%; employees, $\left.58.3 \% ; \chi^{2}(2)=7.4, p=.025\right)$. Also, nearly half of the participants stated they would want to receive information on possible recourse available outside the university to report the incident (students, 46.6\%; professors, 42.7\%; employees, $46.0 \% ; \chi^{2}(2)=6.0, p=.049$ ). Table 6 presents the percentages for other options. 
Table 6. Type of assistance desired, by Status

\begin{tabular}{|c|c|c|c|c|c|c|}
\hline & $\begin{array}{c}\text { Student } \\
\%\end{array}$ & $\begin{array}{c}\text { Professor } \\
\%\end{array}$ & $\begin{array}{c}\text { Employee } \\
\%\end{array}$ & $\chi^{2}$ & $p$ & $\begin{array}{c}\text { Effect sizes } \\
\phi^{\prime}\end{array}$ \\
\hline Support during the reporting process & $71.1^{\mathrm{a}}$ & $64.6^{\mathrm{b}}$ & $72.0^{\mathrm{a}}$ & 22.5 & $<.001$ & .051 \\
\hline $\begin{array}{l}\text { Psychological support from a resource outside } \\
\text { the university }\end{array}$ & $55.2^{\mathrm{ab}}$ & $53.0^{\mathrm{b}}$ & $58.3^{\mathrm{a}}$ & 7.4 & .025 & .029 \\
\hline $\begin{array}{l}\text { Information on possible recourse available within } \\
\text { the university to report the incident }\end{array}$ & $55.4^{\mathrm{a}}$ & $53.4^{\mathrm{a}}$ & $54.0^{\mathrm{a}}$ & 2.1 & .357 & .015 \\
\hline $\begin{array}{l}\text { Information on possible recourse available out- } \\
\text { side the university to report the incident }\end{array}$ & $46.6^{\mathrm{a}}$ & $42.7^{\mathrm{b}}$ & $46.0^{\mathrm{ab}}$ & 6.0 & .049 & .026 \\
\hline $\begin{array}{l}\text { Psychological support from a resource within the } \\
\text { university }\end{array}$ & $48.8^{\mathrm{a}}$ & $34.5^{\mathrm{b}}$ & $38.3^{b}$ & 112.5 & $<.001$ & .113 \\
\hline $\begin{array}{l}\text { Sharing with others who have experienced SVUC } \\
\text { (support group) }\end{array}$ & $28.4^{a}$ & $17.7^{\mathrm{b}}$ & $21.4^{\mathrm{b}}$ & 76.6 & $<.001$ & .093 \\
\hline I don't know & $10.4^{\mathrm{a}}$ & $12.4^{\mathrm{a}}$ & $9.7^{a}$ & 5.4 & .068 & .025 \\
\hline I wouldn't want any assistance & $7.8^{\mathrm{a}}$ & $7.8^{\mathrm{a}}$ & $5.0^{\mathrm{b}}$ & 13.0 & .001 & .039 \\
\hline
\end{tabular}

Note. Proportions that do not share the same letters statistically differ at $p<.05$ in Bonferroni-corrected post hoc comparisons.

While fewer participants indicated they would want to receive psychological support from a resource from within the university, it should be noted that more students (48.8\%) selected this option than professors (34.5\%) and employees $(38.3 \%)\left(\chi^{2}(2)=112.5, p<.001\right)$. The same is true of sharing with others who have experienced SVUC, an option selected by significantly higher numbers of students $(28.4 \%)$ than professors (17.7\%) and employees $(21.4 \%)\left(\chi^{2}(2)=76.6, p<.001\right)$.

\section{Confidants and Witnesses of SVUC}

A substantial proportion of participants reported having witnessed a SVUC incident or acted as a confidant to a victim. While similar numbers of students $(13.7 \%)$, professors (14.4\%) and employees (13.9\%) reported having witnessed an incident of SVUC $\left(\chi^{2}(2)=.4, p=.830\right)$, the same is not true when it comes to acting as a confidant to an SVUC victim. Professors (28.7\%) were significantly more likely to mention they had acted as a confidant than employees (24.6\%) and students $(19.0 \%)\left(\chi^{2}(2)=66.6\right.$, $p<.001)$.

\section{Discussion}

The findings of this study contribute to our understanding of SVUC in the Canadian context and confirm the impor- tance of including professors and employees in SVUC research. While the findings reveal many similarities in the experience of students, professors and employees, the university community is nonetheless a heterogeneous group in which subgroups may face specific challenges, which need to be taken into account to ensure that prevention efforts are achieving their goals.

The fact that more than one third of the students, professors and employees who participated in the study reported having experienced at least one incident of SVUC since beginning their studies or employment at the university indicates that the university setting is not a safe environment for learning or work, especially for some groups. While all university community members may experience SVUC, the data on past-year victimization suggests that being a student is associated with higher odds of sexual violence, compared to being a professor or an employee. This finding confirms the importance of universities being better equipped to meet the needs of university students in terms of prevention and treatment of SVUC. Also, the fact that individuals belonging to gender minorities and women account for particularly high rates of SVUC victims (55.7\% for gender minorities; $40.5 \%$ for women; $26.5 \%$ for men) supports the idea that raising awareness about gendered power relations may reduce the prevalence of sexual violence (Powell \& Henry, 2014). This last result provides needed empirical data 
that document these disparities in a Canadian context and is consistent with other recent studies (e.g. Wright, Dhunna, Riddle, De Gannes \& Berzins, 2019).

Most students, professors and employees who had experienced at least one incident of SVUC stated that in at least one of these incidents the perpetrator held a hierarchically equivalent status to their own. It should be kept in mind, however, that the hierarchical status of the individual who committed the acts was superior to that of the victim significantly more often among employees and professors than among students, suggesting the importance of exploring the power relations inherent to hierarchical relationships among these groups and, more specifically, to workplace harassment. The data also reveal that the majority of students, professors and employees (between $78.4 \%$ and $92.1 \%$ depending on the status) reported that at least one incident of SVUC involved a male perpetrator. These results point to the importance of locating sexual violence within the wider frame of men's violence against women (Powell \& Henry, 2014).

The experience of sexual violence in a university setting is associated with noteworthy repercussions in different spheres of the lives of victims, regardless of the victims' university status $(47.6 \%$ of the sample reported experiencing at least one consequence). Some $10 \%$ of victims suffer symptoms associated with post-traumatic stress. In these situations, the school or work setting becomes an unsafe place for the victim of SVUC, who develops strategies to avoid certain locations or individuals, and is constantly on alert to prevent any new incidents of sexual violence.

The disturbing rates of SVUC and its consequences emphasize the importance of preventing SVUC, facilitating reporting, and supporting victims. To this point, more than nine out of ten participants either did not report or reported only certain incidents to university authorities or resources, with significantly fewer students reporting all the incidents to which they were subjected. The reasons most frequently given for not reporting SVUC concern the perception of the situation's severity and the desire to put the incident behind them and forget about it. Most of the reasons given by participants were selected in similar proportions by students, professors and employees. However, significantly more students stated they did not report because they were afraid that they did not have sufficient evidence to convince university authorities to act, or they did not know who to contact at the university or were unaware that the university could help them in this situation. This would certainly explain the students' lower reporting rate. The data also reveal that employees and professors were more numerous than students in stating they did not report the incidents out of fear of negative consequences regarding their jobs, academic session, obtaining their degree, or their athletic career. This is not surprising, given the fact that significantly more employees and professors than students reported that the perpetrator's hierarchical status was higher than their own. It suggests that particular attention needs to be paid to situations in which the perpetrator was in an authority position because the power relationship attached to hierarchical status makes reporting much more difficult. Lack of reporting also highlights the importance of creating safe and accountable campus climates to enable victims to report without fear of retaliation.

When questioned about desired assistance, most students, professors and employees affirmed they would want support during the reporting/complaint process, information about possible recourse provided by a resource within the university to report the incident, and psychological support provided by resources outside the university. In addition, proportionately more students selected the options of psychological support provided by a resource within the university and support groups. These results emphasize the need to implement a diversified set of services for the entire university community so that each person can choose the options that best meet their needs.

Last, a striking proportion of participants reported having witnessed a SVUC incident or acted as a confidant to a victim. While a similar proportion of students, professors and employees witnessed an incident of SVUC (roughly one out of eight), the finding is different with respect to acting as the confidant of an SVUC victim. Significantly more professors (28.7\%) acted as confidant to a victim than employees (24.6\%) and students (19.0\%), pointing to the need to promote awareness of all groups in the university community, including professors, who appear to serve as resource people. These findings are consistent with various studies suggesting that professors frequently receive information and disclosures from students in SVUC situations (Branch, Hayes-Smith, \& Richards, 2011) and confirm the relevance of developing and implementing programs targeting students, employees and faculty as they are likely to be potential witnesses or confidants of SVUC situations. 


\section{Contributions and Limits of the Study}

This study contributes to the understanding of the problem of sexual violence experienced on university campuses (excluding events involving perpetrators from outside the institution). Our findings highlight similarities and differences for students, professors and employees regarding the rate of SVUC, witnesses and confidants, the relationship between perpetrators and victims, reporting to university authorities, and the desired types of assistance. Our study documents three forms of sexual violence (sexual harassment, unwanted sexual behaviors, and sexual coercion) during two reporting periods and considers SVUC committed both on and off campus.

As with any research, this study has certain methodological limits, the main ones having to do with the sample's representativeness. Firstly, the research was based on a convenience sample, as is true of many other studies. Secondly, because the sample could not be weighted, results cannot be generalized to the university population as a whole. Also, since the objective of the analysis already required cutting the sample into three subsamples (students, professors, employees), we could not perform analyses for all minority groups. For this reason, this article was not able to examine racial, ethnic and indigenous differences, nor sexual orientation, age or disability to more accurately understand the potential differential impacts for marginalized groups. Further studies would benefit from taking into account these variables to propose an intersectional analysis of SVUC. One must also consider that by targeting current members of university community, we were unable to reach the students or workers who left the university as a result of SVUC. Finally, while our results identify significant differences among groups, it should be kept in mind that generally the effect sizes are small, revealing that the groups (students, professors, employees) are distinguished by small differences for some of the variables considered. However, the advantage of this study is that it provides data that are specific to Canadian university campuses and that include the entire university community.

\section{Conclusion}

Given the low reporting rates, the study suggests that institutional statistics - based on formal reports - cannot be considered as valid indicators of the extent of SVUC. Indeed, such indicators represent only the tip of the ice- berg, as many situations remain undisclosed to anyone and the vast majority are not reported. Results confirm a real problem of sexual violence for students, professors and employees. There is clearly a need for effective policies and actions with a "zero tolerance attitude." Sexual violence in institutions concerns all groups in the university community and prevention strategies must address all of them, including institutional policy and training and awareness programs. In this respect, the recent Bill 22.1, An Act to Prevent and Fight Sexual Violence in Higher Education Institutions unanimously adopted by the Québec government in December 2017 (RLRQ, 2017, c. 32, c. I.), explicitly prescribes measures applying to students and staff members.

Based on the research findings, and from the perspective of social transformation, the Enquête Sexualité, Sécurité et Interactions en Milieu Universitaire (ESSIMU) team proposed 15 recommendations for the prevention of sexual violence on university campuses which can be found in the research report (Bergeron et al., 2016). They are grouped into six focal areas: 1) framework policy and stand-alone SVUC prevention policy; 2) safe environment; 3) awareness based on permanent strategies adapted to different groups; 4) education and training; 5) specialized support interventions accessible to the whole university population; and, 6) research. These recommendations are intended to provide members of the university community with a healthy, egalitarian and secure learning and work environment, free from sexual violence.

\section{Acknowledgements}

The authors wish to acknowledge funding for this project from the Réseau québécois en études féministes/Québec network of feminist studies (RéQEF), a grant from the Service aux collectivités/Services to the communities of UQAM, and the Women's Program at Status of Women Canada. The authors also wish to thank Manon Robichaud for processing the data. Finally, the authors would like to thank the participants who generously gave their time to this study.

\section{References}

Baker, N. V. (2010). Challenging Sexual Harassment on Campus. Forum on Public Policy Online, 2010, (5). 
Banyard, V. L., Ward, S., Cohn, E. S., Plante, E. G., Moorhead, C. A. E., \& Walsh, W. A. (2007). Unwanted sexual contact on campus: a comparison of women's and men's experiences. Violence and Victims, 22(1), 52-70.

Basile, K. C., Smith, S. G., Breiding, M. J., Black, M. C., \& Mahendra, R. R. (2014). Sexual Violence Surveillance: Uniform Definitions and Recommended Data Elements, Version 2.0. Atlanta, GA: National Center for Injury Prevention and Control, Centers for Disease Control and Prevention. Retrieved from https://www.cdc.gov/violenceprevention/pdf/sv surveillance definitionsl-2009-a.pdf

Bastiani, F., Romito, P., \& Saurel-Cubizolles, M. J. (2018). Mental distress and sexual harassment in Italian university students. Archives Of Women's Mental Health, 1-8.

Bergeron, M., Hébert, M., Ricci, S., Goyer, M.-F., Duhamel, N., Kurtzman, L., Auclair, I., Clennet-Sirois, L., Daigneault, I., Damant, D., Demers, S., Dion, J., Lavoie, F., Paquette, G., \& Parent, S. (2016). Violences sexuelles en milieu universitaire au Québec : Rapport de recherche de l'enquête ESSIMU. Montréal : Université du Québec à Montréal. Retrieved from http://essimu.quebec/wp/wp-content/ uploads/2015/12/Rapport-ESSIMU COMPLET.pdf

Bradshaw, J. (2014, March 3) University of Ottawa men's hockey team suspended over alleged sex assault. The Globe and Mail. Retrieved from https:ll www.theglobeandmail.com/news/national/university-of-ottawa-suspends-hockey-team-over-serious-misconduct/article17201525/

Branch, K. A, Hayes-Smith, R., \& Richards, T. N. (2011). Professors' experiences with student disclosures of sexual assault and intimate partner violence: How "helping" students can inform teaching practices", Feminist Criminology, 6(1), 54-75.

Brennan, S., \& Taylor-Butts, A. (2008). Sexual assault in Canada. Canadian centre for justice statistics profile series. Catalogue 85F0033M - No. 19. Ottawa: Statistics Canada.

Canadian Federation of University Women. (2016). Mémoire au Comité de la condition féminine pour étayer son étude intitulée "La violence envers les jeunes femmes et filles au Canada". Ottawa, Ontario : Canadian Federation of University Women. Retrieved from http://www.parl.gc.ca/Content/ HOC/Committee/421/FEWO/Brief/BR8406529/ br-external/CanadianFederationofUniversityWomen-9437755-f.pdf

Cantin, S., \& Proulx, C. (1995). À l'université comme ailleurs: rapport du sondage sur le harcèlement sexuel mené à l'Université de Montréal. Montréal, Québec: Université de Montréal.

Cloutier, P. (2016, October 16). Vague d'agressions sexuelles en une nuit à l'Université Laval. Le Soleil. Retrieved from https://www.lesoleil.com/actualitel justice-et-faits-divers/vague-dagressions-sexuelles-en-une-nuit-a-luniversite-laval-579a2342e$\underline{315383 c 914 b 4 \mathrm{efb} 1 \mathrm{f} 201218}$

Cohen, J. (1988). Statistical power analysis for the behavioral sciences (2nd ed.). Hillsdale, NJ: Lawrence Earlbaum Associates.

Colpron, S., \& Hétu, R. (1993, February 20). Les agressions sexuelles sur les campus à Montréal. La Presse.

DeKeseredy, W., \& Kelly, K. (1993). The incidence and prevalence of woman abuse in Canadian university and college dating relationships. Canadian Journal of Sociology, 18(2), 137-159.

Elkouri, R. (2015, september 11). Désolé pour votre agression. La Presse. Retrieved from http://plus. lapresse.ca/screens/e98203ad-1916-48a6-85863f8e83949b53 7C $0 . \mathrm{html}$

Fedina, L., Holmes, J. L., \& Backes, B. L. (2016). Campus Sexual Assault: A Systematic Review of Prevalence Research From 2000 to 2015. Trauma, Violence, \& Abuse, 19(1), 76-93.

Fisher, B. S., Cullen, F. T., \& Turner, M. G. (2000). The sexual victimization of college women. Washington, DC: National Institute of Justice.

Fitzgerald, L. F., Gelfand, M. J., \& Drasgow, F. (1995). Measuring sexual harassment: Theoretical and psychometric advances. Basic and applied social psychology, 17(4), 425-445.

Fitzgerald, L. F., Magley, V. J., Drasgow, F., \& Waldo, 
C. R. (1999). Measuring sexual harassment in the military: The Sexual Experiences Questionnaire (SEQ—DoD). Military Psychology, 11(3), 243-263.

Fitzgerald, L. F., Shullman, S. L., Bailey, N., Richards, M., Swecker, J., Gold, Y., Ormerod, M., \& Weitzman, L. (1988). The incidence and dimensions of sexual harassment in academia and the workplace. Journal of vocational behavior, 32(2), 152-175.

Government of British Columbia. (2016). Sexual violence and misconduct policy act. SBC 2016, c. 23. Retrieved from http://www.bclaws.ca/civix/document/id/complete/statreg/e3tlc16023

Government of Ontario. (1990). Sexual violence at colleges and universities. R.S.O. 1990, c. M.19, O. Reg. 131/16. Retrieved from https://www.ontario.cal laws/regulation/160131

Government of Québec. (2017) Act to prevent and fight sexual violence in higher education institutions. RLRQ, c. P-22.1. Retrieved from http://legisquebec. gouv.qc.ca/fr/ShowDoc/cs/P-22.1

Haaken, J. (2017). Many mornings after: Campus sexual assault and feminist politics. Family Relations, 66(1), 17-28.

Hanmer, J. (1977). Violence et contrôle social des femmes. Nouvelles Questions féministes, 2(novembre), 68-88. Retrieved from https://www.feministes-radicales.org/wp-content/uploads/2012/03/ Jalna-Hanmer-Violence-et-contr\%C3\%B4le-socialdes-femmes-1977-Copie.pdf

Hill, C., \& Silva, E. (2005). Drawing the line: Sexual harassment on campus. Washington, DC: AAUW Educational Foundation.

Iconis, R. (2006). Sexual harassment on campus: Development of policies \& procedures at the city university of New York. Journal of College Teaching \& Learning, 3(12), 61-74.

Kelly, L. (1987). The Continuum of Sexual Violence. In J. Hanmer \& M. Maynard (Eds.), Women, violence, and social control (pp. 46-60). Atlantic Highlands, N.J. : Humanities Press International.

Krebs, C., Lindquist, C., Berzofsky, M., Shook-Sa, B., Peterson, K., Planty, M., Langton, L., \& Stroop, J.
(2016). Campus Climate Survey Validation Study Final Technical Report. Washington, DC: Bureau of Justice Statistics Research and Development Series.

Krebs, C. P., Lindquist, C. H., Warner, T. D., Fisher, B. S., \& Martin, S. L. (2007). The Campus Sexual Assault (CSA) Study: Final Report. Washington, DC: National Institute of Justice.

Krug, E. G., Mercy, J. A., Dahlberg, L. L., \& Zwi, A. B. (2002). World Report on Violence and Health. Geneva : World Health Organization. Retrieved from https://www.who.int/violence injury prevention/ violence/world report/en/

Powell, A. \& Henry, N. (2014). Framing Sexual Violence Prevention. What Does It Mean to Challenge a Rape Culture? In Henry, N. \& A. Powell (Eds.), Preventing sexual violence: Interdisciplinary approaches to overcoming a rape culture (p. 25-80). Basingstoke, UK : Palgrave Macmillan.

Prins, A., Ouimette, P., Kimerling, R., Cameron, R. P., Hugelshofer, D. S., Shaw-Hegwer, J., Thrailkill, A., Gusman, F., \& Sheikh, J. I. (2004). The primary care PTSD screen (PC-PTSD): Development and operating characteristics. Primary Care Psychiatry, 9(1), 9-14.

Quinlan, E., Clarke, A., \& Miller, N. (2016). Enhancing care and advocacy for sexual assault survivors on Canadian campuses. The Canadian Journal of Higher Education, 46(2), 40-54.

Quinlan, E., Quinlan, A., Fogel, C., \& Taylor, G. (Eds.). (2017). Sexual Violence at Canadian Universities: Activism, Institutional Responses, and Strategies for Change. Waterloo, Ontario: Wilfrid Laurier Univ. Press.

Taber, J. (2014, December 15) Dalhousie dental school investigates misogynistic Facebook comments.

The Globe and Mail. Retrieved from https://www. theglobeandmail.com/news/national/dalhousie-dental-school-investigates-misogynistic-facebook-comments/article22111008/

Tremblay, P. F., Harris, R., Berman, H., MacQuarrie, B., Hutchinson, G. E., Smith, M. A., Braley, S., Jelley, J., \& Dearlove, K. (2008). Negative social experi- 
ences of university and college students. The Canadian Journal of Higher Education, 38(3), 57-75.

Tutton, M. (2013, September 4) Saint Mary's University frosh chant cheers for rape, underage sex. Global News. Retrieved from https://globalnews.cal news/819744/saint-marys-university-frosh-chantcheers-for-rape-underage-sex/

University of Ottawa. (2015). Report of the Task Force on Respect and Equality: Ending Sexual Violence at the University of Ottawa. Ottawa, Canada: University of Ottawa. Retrieved from https://www.uottawa. ca/president/sites/www.uottawa.ca.president/files/ report-of-the-task-force-on-respect-and-equality.pdf

Wright, J., Dhunna, S., Riddle, T., De Gannes, P., \& Berzins, T. (2019). End the Silence, End the Violence: Experiences and Understandings of Sexual Violence at the University of Toronto. Toronto, Ontario: Silence is Violence.

\title{
Contact Information
}

\author{
Manon Bergeron, $\mathrm{PhD}$ \\ bergeron.manon@uqam.ca
}

\section{Notes}

1 The overall study sample also comprises participants who hold managers positions. Because we were unable to conduct valid comparative analyses due to the low number of managers, this subgroup was not included in these analyses.

2 In Québec, undergraduate studies consist primarily of Bachelor's, certificate, and short programs; graduate degrees include the Master's, Ph.D., and Specialized Graduate Diploma (DESS) programs.

3 According to Cohen (1988), equivalences for small, medium, and large effects should be established based on the smallest number of categories $(r)$ in the contingency table (if $r=2, .10, .30$, and .50 , respectively; if $r=3, .071, .212$, and .354 , respectively; if $r=$ $4, .058, .173$, and .289 , respectively). 